plication to the cyclones of middle and higher latitudes, as it presupposes simple whirls like the symmetrical cyclone of the tropics. J. vON HANN.

Vienna, February.

\section{The Ascent of Mount Everest.}

THE opportunity which mountaineers and geographers have long looked for of approaching Mount Everest from the north has at last arrived. The Tibetan Government has given its consent for the dispatch of an expedition to explore the mountain. The expedition is now being organised by a combined committee of the Royal Geographical Society and the Alpine Club, and an attempt will be made to ascend this the highest mountain in the world.

The cost of the expedition is estimated at about ro,oool. Already a quarter of this amount has been raised among the members of the two societies. But the expedition will have to leave England very shortly, and it is essential to its success that the equipment shall be the best possible, and that no financial uncertainty shall delay the organisation in India of a picked corps of Himalayan porters and of an adequate transport service. Heavy initial outlay is therefore involved, and we now appeal to the general public, confident that it will wish to further an enterprise the successfut accomplishment of which will bring so much credit to this country.

Subscriptions should be sent to the Treasurer, Royal Geographical Society, Kensington Gore, S.W.7, or tc the Bank of Liverpool and Martins (Cocks, Biddulph, and Co.'s branch), 43 Charing Cross, S.W.I. Francis Younghusband,

President, Royal Geographical' Society. J. N. Collie,

President, Alpine Club.

February 23.

\section{Pure Organic Chemicals.}

I AM glad to see that the writer of the leading article in NATURE of February 24 directs attention to the concern with which research workers view the possibility of foreign organic chemicals being restricted or excluded by legislation in the interests of British manufacturers.

The latter are not yet in a position to supply many materials in that state of unquestioned purity such as: one associates with the old firms of Merck and Kahlbaum in Germany and Poulenc Frères in France.

As an illustration I may mention that I recently ordered a pound of propyl alcohol (as catalogued) from a British firm, and at the same time a like quantity from Poulenc Frères. The first forwarded a material costing $18 s$. which consisted of a mixture boiling over a wide range of temperature but containing no propyl alcohol, whereas the French firm supplied a pure sample of nearly constant boiling point costing Ixs., including postage.

The University, Leeds, February 25.

\section{Nature of Vowel Sounds.}

WITH regard to the very interesting researches on vowel sounds by Prof. Scripture published! in Nature of January I3 (p. 632) and January 20 (p. 664), I beg to be permitted to state that the attempt of Helmholtz to produce vowels with smooth, simple tones has since been fully confirmed. Using, instead of tuningforks, bottles caused to sound by currents of air blown over their orifices; which, as is well known, give almost perfectly simple tones, I have been able to demonstrate this myself. The remarkable and extended investigations of Prof. Miller described in his book, "Science of Musical Sound," have fully proved the statement of Helmholtz to be true, as have also the researches of Prof. Stumpff, of Berlin. I am therefore of the opinion that the Helmholtz theory of vowel sounds can scarcely be doubted any longer. Hermann's and Scripture's method of producing vowels by sending puffs of air through a resonator does not contradict this. Whenever a complex vibration is set up which appears to be a mixture of simple tones corresponding to the sound of a vowel, there will be produced a vowel. However, it is very important to have repeated Hermann's experiments and extended them by using resonators with soft walls.

Hôtel Eden, Montreux, Switzerland.

Charles DE Wesendonk.

THE above letter very properly directs attention to the excellent work of Prof. Miller. It is worth while to study Fig. I30 of his book, reproduced below. For the tuning-fork there is only one tone, namely, the fundamental. For the other instruments the fundamental appears clearly, but for the voice the fundamental is lacking. Thus the strongest tone in a vowel, the voice tone, does not appear in the plot. This is in agreement with the work of Hermann and myself. As explained in Nature of January 13 and 20 , this arises from the fact that the voice tone consists of a series of puffs.
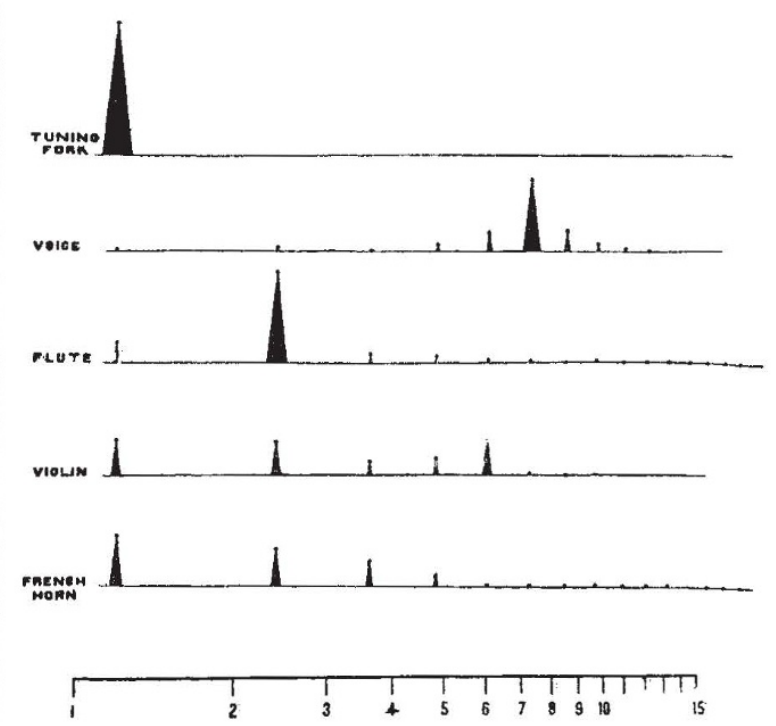

FIG. I.-Diştribution of energy in sounds from various sources

Prof. Miller's plots show that for the musical instruments the harmonics appear strongly at certain places. For the voice, however, the seventh, eighth, and ninth harmonics appear. Three tones in the relations $7: 8: 9$ sounded together would produce a most discordant sound with disturbing beats, and certainly not the clear tone that characterises a vowel. As explained in NATURE, such a group of neighbouring harmonics arises from the presence of an inharmonic in this region which can express itself only in this way.

I't is interesting to note that Prof. Miller's results give direct evidence of both elements of the new vowel theory, namely, that the voice tone consists of a series of puffs, and that the vowel tones are independent of the pitch of the voice tone. From Prof. Miller's plots they would appear always to be inharmonic.
E. W. Scripture. No. 2679 , VOL. IO7] 